\title{
EKSTRAKSI KARAKTERISTIK WAJAH MANUSIA DENGAN TRANSFORMASI WARNA YCbCr
}

\author{
T. Rahmad Effendi ${ }^{1}$, Nurul Fadillah ${ }^{2}$ \\ Program Studi Teknik Informatika \\ Universitas Samudra \\ trahmadeffendi@gmail.com \\ nurulfadillah@unsam.ac.id
}

\begin{abstract}
Abstrak
Abstrak - Kulit adalah organ terluar tubuh yang melapisi seluruh tubuh manusia dan dapat digunakan sebagai media informasi, seperti proses deteksi wajah, diagnosa medis dan lain-lain. Dalam deteksi kulit banyak dipengaruhi oleh beberapa faktor seperti cahaya, latar belakang, kesesuaian kamera dan sebagainya. Dalam penelitian ini, deteksi kulit menggunakan model warna $\mathrm{YCbCr}$, dan pengkodean akan dilakukan menggunakan aplikasi Mathlab. Dalam hal ini, metode transformasi sistem ruang warna sebagai bagian dari pemrosesan gambar membantu dalam mendeteksi warna dalam gambar dan memprosesnya sehingga mudah untuk diidentifikasi. Sebelum deteksi kulit pada wajah dilakukan, pengenalan wajah dilakukan terlebih dahulu menggunakan ekstraksi fitur, ekstraksi fitur adalah proses untuk mengetahui lokasi wajah dalam sebuah gambar. Dalam penelitian ini menggunakan gambar yang diambil secara offline, dan hasil penelitian ini adalah $\mathrm{Cr}$ dan $\mathrm{Cb}$, dan hasil terbaik ketika proses Binarisasi memiliki $\mathrm{Cb}=75$ dan $\mathrm{Cr}=145$.
\end{abstract}

\section{Kata Kunci : YCbCr, Kulit, Binarization}

\section{Pendahuluan}

Ekstraksi fitur dapat digunakan untuk proses pengenalan wajah dan akan dilakukan pendeteksian pada kulit. Kulit dapat dijadikan sumber informasi yang sangat relevan, proses yang dilakukan ialah pendeteksian pada wajah. Keuntungan yang dapat diperoleh jika kulit dijadikan sebagai sumber awal informasi untuk proses-proses yang disebutkan di atas antara lain 
adalah memungkinkannya pemrosesan yang cepat dan langsung, tahan (robust) terhadap variasi geometris dari pola-pola/tekstur kulit, tahan terhadap perubahan resolusi citra dan mengurangi kebergantungan pada penggunaan peralatan penjejakan yang khusus. Selain itu karena kulit memiliki karakteristik warna, maka hal ini memberikan kemudahan lain karena warna adalah salah satu aspek yang dengan cepat dan mudah dapat dikenali oleh manusia.

Terdapat berbagai penelitian yang telah dilakukan untuk melakukan deteksi posisi dan ekstraksi fitur wajah pada suatu citra berwarna. Pada penelitian deteksi posisi wajah dilakukan pada suatu citra berwarna dengan memanfaatkan informasi piksel warna kulit dan informasi lubang pada wajah.

Warna kulit setiap orang yang beragam tidak selalu sama, hal ini disebabkan beberapa factor yang menentukan warna kulit. Ada 2 kelompok faktor penentu warna kulit, yaitu kelompok factor internal dan kelompok faktor eksternal. Diantara kelompok faktor internal antara lain faktor ras, keturunan dan genetik. Sedangkan faktor eksternal seperti kebiasaan hidup seseorang lifestyle (sering tidaknya terkena sinar UV matahari, merokok, minum obat antibiotik tertentu dengan bahan aktif minocycline) dan perawatan kulit serta konsistensi pemakaian produk kosmetik yang aman dan efektif.

Pada penelitian ini mengklasifikasikan warna kulit dengan mendeteksi piksel kulit dan bukan kulit. Pada penelitian ini dilakukan secara otomatis pada proses segmentasinya. Beberapa teknik pengolahan citra dilakukan seperti proses biner, threshold, proses morfologi dan juga segmentasi. Pada penelitian, Proses Binarization dilakukan menggunakan metode otsu's thresholding dari citra keabuan.

Pada penelitian ini digunakan metode transformasi warna YCbCr . Pada metode ini akan memisahkan nilai RGB menjadi informasi luminance dan chrominance yang berguna untuk aplikasi kompresi. Ruang warna RGB pada citra asli masih mengandung efek cahaya yang menyebabkan karakteristik warna kulit bias berubah, karenanya perlu dikonversi ke dalam bentuk warna kromatik. Untuk mengurangi efek pencahayaan itu digunakan model warna $\mathrm{YCbCr}$, model warna ini terdiri dari 3 
komponen yaitu : Y bernilai luminance (tingkat keterangan), $\mathrm{Cb}$ bernilai Chrominance Blue ( tingkat kebiruan) dan $\mathrm{Cr}$ bernilai Chrominance Red (tingkat kemerahan). Pada penelitian ini menggunakan beberapa sample tipe wajah manusia dengan tipe warna kulit yang berbeda. Metode transformasi warna $\mathrm{YCbCr}$ ini menggunakan Mathlab.

\section{Tinjauan Pustaka}

\subsection{Ruang Warna Pada Citra}

Model warna $\mathrm{YCbCr}$ merupakan standar internasional bagi pengkodean digital gambar televisi yang didefinisikan di CCIR Recommendation 601. Y merupakan komponen luminance, $\mathrm{Cb}$ dan $\mathrm{Cr}$ adalah komponen chrominance. Pada model ini, monitor monokrom nilai luminance digunakan untuk merepresentasikan warna RGB, secara psikologis ia mewakili intensitas sebuah warna RGB yang diterima oleh mata. Chrominance merepresentasikan corak warna dan saturasi (saturation).

Ruang warna $\mathrm{YCbCr}$ biasa digunakan untuk video digital. Konversi warna YCbCr dapat diperoleh dari model RGB dengan matriks berikut:

$$
\begin{aligned}
& Y=0,299900 R+0,58700 G+0,11400 B \\
& C b=-0,16874 R-0,33126 G+0,5000 B \\
& C r=0,5000 R-0,41869 G-0,08131 B
\end{aligned}
$$

dengan $\mathrm{Y}$ adalah luminance untuk komponen green (G) yang dinyatakan sebagai komponen kecerahan, $\mathrm{Cb}$ adalah crominance untuk komponen blue (B) sebagai informasi kecerahan dan $\mathrm{Cr}$ adalah crominance untuk komponen red (R) sebagai informasi kecerahan.

\subsection{Metode Diusulkan}

Pada penelitian ini dibuat sebuah program untuk mendeteksi kulit pada citra berwarna dan pengimplementasian metode transformasi warna $\mathrm{YCbCr}$. 


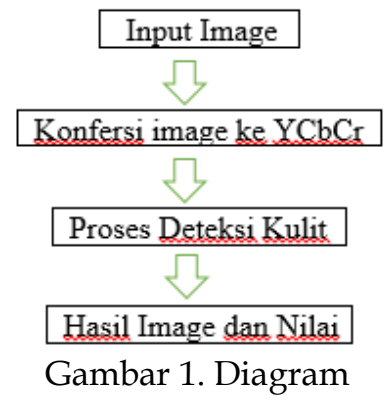

Pada diagram diatas dapa dijelaskan awalnya input gambar wajah seseorang, lalu dilakukan proses konfersi image ke $\mathrm{YCbCr}$, selanjutnya proses pemisahan kulit dan bukan kulit. Selanjutnya mendapak nilai rata-rata dari $\mathrm{Y}, \mathrm{Cr}$ dan $\mathrm{Cb}$

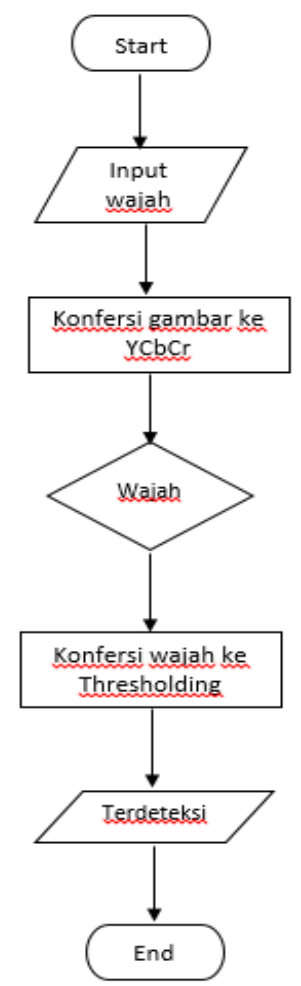

Gambar 2. Flowchart 
Pada flowchart diatas mulai dari menginputkan wajah seseorang lalu akan dikonfersikan dari RGB ke YCbCr, lalu akan terdeteksi wajah yang telah diinputkan tadi, selanjutnya konfersi ke Thresholding dan wajah terdeteksi.

\subsection{Memproses dengan metode $\mathrm{YCbCr}$}

Pada penelitian ini menggunakan metode ruang warna $\mathrm{YCbCr}$, untuk proses konfersi ini dilakukan dengan memaukkan wajah dengan citra RGB dan akan dikonfersi ke $\mathrm{YCbCr}$, konfersi ini menggunakan mathlab. Gambar 3 adalah contoh konfersi ke YCbCr.
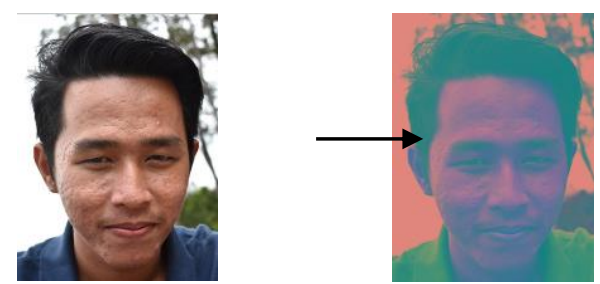

Gambar 3. Hasil Konversi ke YCbCr

Proses selanjutnya yaitu segmentasi kulit mengunakan batasan nilai range piksel kulit pada masing-masing metode. Nilai-nilai range ini diambil berdasarkan kisaran piksel warna kulit. Peneliti mengambil batas atas dan bawah dari ke dua metode ini berasal dari penelitian-penelitian sebelumnya tentang segmentasi kulit.

Pada metode $\mathrm{Ycrcb}$, nilai range berdasarkan pada nilai $\mathrm{cr}$ dan $\mathrm{cb}$. $\mathrm{Y}$ atau luminance tidak menggunakan range karena $\mathrm{Y}$ merupakan pencahayaan dalam suatu citra gambar.

\section{Hasil dan Pembahasan}

Pada hasil pengujian Ycrcb dapat disimpulkan bahwa output image $Y$ adalah sama halnya dengan image grayscale atau keabuabuan dengan mempunyai nilai asli dari sample image. Sedangkan pada Cr mempunyai kemurnian warna yang cukup tinggi, dimana image yang terdeteksi benda lebih terang. Sedangkan untuk $\mathrm{cb}$ adalah mempunyai nilai yang digelapkan sehingga terlihat perbedaannya yang sedikit mencolok. 
Ekstraksi Karakteristik Wajah Manusia Dengan Transformasi

Table 1. Pengkonverisan Citra Asli Ke Ycbcr

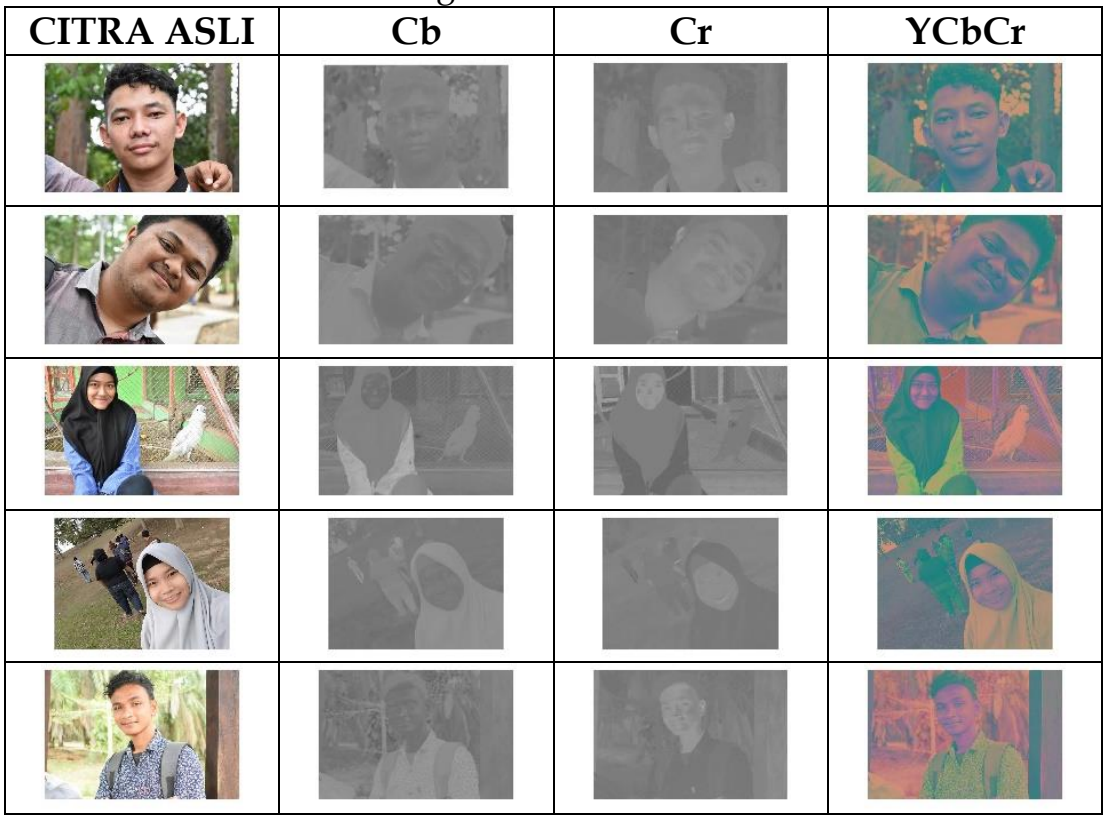

Table 2. Hasil Binarization

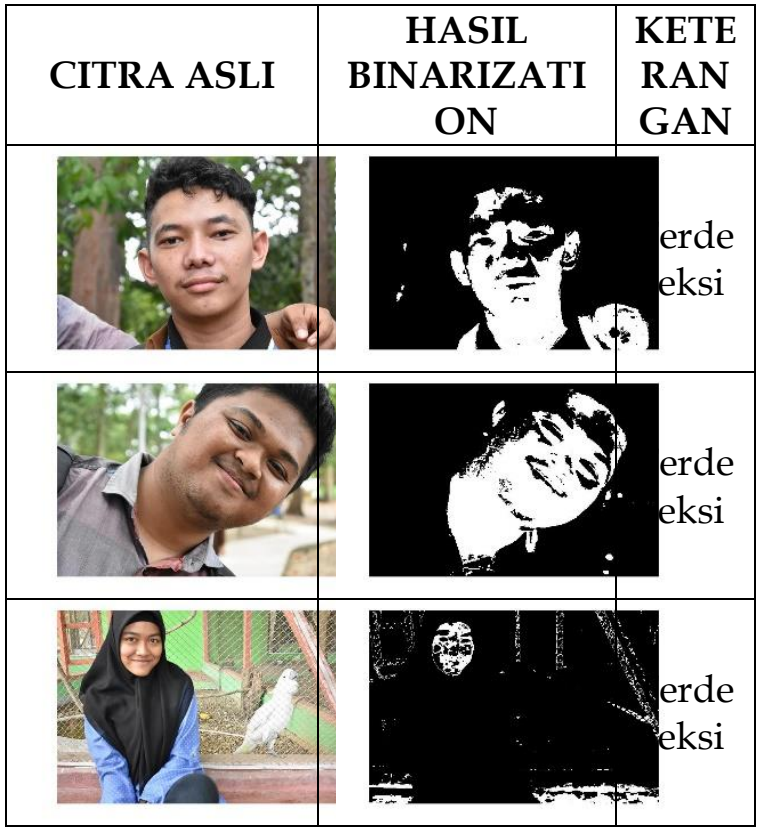




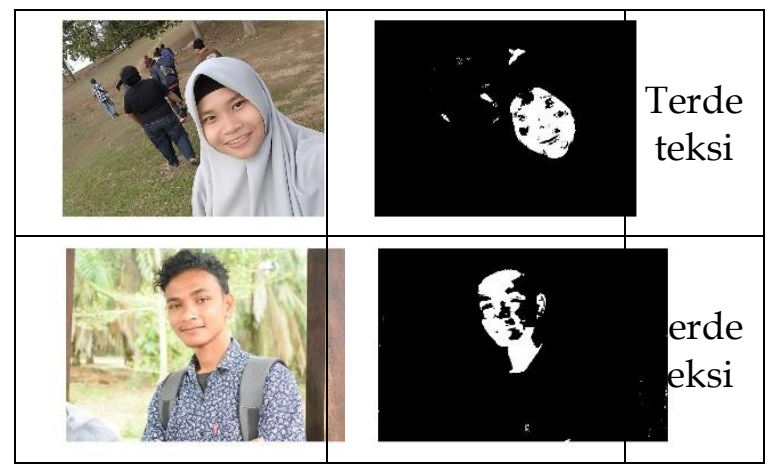

Dari hasil pengujian proses binarization atau proses segmentasi kulit didapatkan hasil seperti yang diharapkan yaitu jika piksel warna termasuk dalam range piksel kulit maka tercetak warna putih dan jika bukan termasuk piksel warna kulit maka tercetak warna hitam (0). Pada pengujian tabel di atas adalah proses binarization dengan metode transformasi warna Ycrcb. Pada metode transformasi warna Ycrcb bekerja sangat baik dalam proses segmentasi kulit, walaupun masih sedikit terdapat kesalahan deteksi misalnya rambut yang menyerupai piksel kulit masih bias terdeteksi kulit.

Table 3. Nilai Range Kulit Pada $\mathrm{Cb} \& \mathrm{Cr}$

\begin{tabular}{|c|c|c|c|c|}
\hline No & Cb bawah & Cb bawah & Cr atas & Cr atas \\
\hline 1 & 70 & 130 & 137 & 170 \\
\hline 2 & 80 & 125 & 135 & 160 \\
\hline 3 & 85 & 130 & 145 & 150 \\
\hline 4 & 77 & 125 & 140 & 173 \\
\hline 5 & 80 & 127 & 145 & 180 \\
\hline
\end{tabular}

Dari pengujian diatas Warna kulit sebagian besar ditentukan oleh nilai dari komponen $\mathrm{Cb}$ dan $\mathrm{Cr}$. Komponen nilai $\mathrm{Y}$ bergantung pada kondisi pencahayaan.

\section{Kesimpulan}

Pada hasil pengujian Ycrcb dapat disimpulkan bahwa output image $\mathrm{Y}$ adalah sama halnya dengan image grayscale atau keabuabuan dengan mempunyai nilai asli dari sample image. 
Sedangkan pada Cr mempunyai kemurnian warna yang cukup tinggi, dimana image yang terdeteksi benda lebih terang. Sedangkan untuk $\mathrm{cb}$ adalah mempunyai nilai yang digelapkan sehingga terlihat perbedaannya yang sedikit mencolok Pada proses binarization dapat disimpulkan bahwa jika piksel warna termasuk dalam range piksel kulit maka tercetak warna putih (255) dan jika bukan termasuk piksel warna kulit maka tercetak warna hitam (0).

\section{Daftar Pustaka}

Enny Indasyah, Elsen Ronando, “Ekstraksi Ciri Menggunakan Metode Transformasi Warna Ycbcr Untuk Klasifikasi Kulit Manusia", Desember 2017

Iping Supriana, Yoseph Suryadharma, "Deteksi Posisi dan Ekstraksi fitur wajah manusia pada citra berwarna", November 2009

Murinto, Eko Aribowo, Wahyu Nurhidayati, “Deteksi Jenos Warna Kulit Wajah untuk Klasifikasi Ras Manusia Menggunkan Transformasi Warna", Jogjkarta

Rony Wijanarko, Nugroho Eko, “Deteksi Wajah Berbasis Segmentasi Warna Kulit Menggunakan Ruang Warna Ycbcr \& Template Matching", Semarang

Tri Afirianto, Faizatul Amalia, "Pengaruh Komponen Krominan Pada Ruang Warna Hsv, Ycbcr, Dan Cielab Untuk Deteksi Kulit Menggunakan Klasifikasi Knn", November 2016 